\title{
Стан нейродинамічних функцій і динамічна м'язова витривалість кваліфікованих спортсменів- веслувальників
}

\author{
УДК 797.122.2/3.015:159.91 \\ С. Федорчук' ${ }^{1}$ В. Кравченко ${ }^{2}$, К. Фібах ${ }^{2}$, \\ О. Лисенко ${ }^{1,3}$, О. Шинкарук ${ }^{1}$
}

\begin{abstract}
${ }^{1}$ Національний університет фізичного виховання і спорту України, Київ, Україна ${ }^{2}$ Київський національний університет імені Тараса Шевченка, Київ, Україна ${ }^{3}$ Київський університет імені Бориса Грінченка, Київ, Україна

Резюме. Досліджено показники простої зорово-моторної реакції та реакції вибору одного 3 трьох сигналів для правої та лівої руки, показники реакції вибору двох із трьох сигналів. Крім того, за показниками тепінг-тесту окремо для правої та лівої кисті досліджували динамічну м'язову витривалість. Мета. Визначення і порівняння стану нейродинамічних функцій і динамічної м'язової витривалості руху кисті спортсменів, які спеціалізувалися в циклічному виді спорту (веслування на байдарках і каное) і нетренованих осіб (студентів). Методи. Аналіз наукової літератури, тестування, методи математичної статистики. Результати. За психофізіологічними показниками спортмени продемонстрували вищі результати, деякі відмінності досягли рівня значущості. Спортсмени порівняно з нетренованими особами продемонстрували вищу м'язову витривалість під час рухів кисті домінантної руки та вищу швидкість обробки інформації в центральній нервовій системі, що проявлялося у швидших реакціях вибору двох із трьох сигналів та коротшим часом центральної обробки інформації. Латентні періоди простої зорово-моторної реакції в обстежених спортсменів і нетренованих осіб не відрізнялися. Отримані дані свідчать про зміни передусім у центральних ланках організації рухових програм унаслідок тренування, тоді як периферичні компоненти сенсомоторних реакцій меншою мірою зазнають перебудови внаслідок регулярних фізичних навантажень. Виявлені відмінності стану нейродинамічних функцій і рівня динамічної м'язової витривалості руху кисті можуть мати прогностичну цінність і використовуватися для оптимізації спортивного вдосконалення в даному виді спорту. Ключові слова: спортсмени високої кваліфікації, стан нейродинамічних функцій, динамічна м'язова витривалість, веслування.
\end{abstract}

\section{State of neurodynamic functions and dynamic muscular endurance of skilled rowers}

\section{S. Fedorchuk', V. Kravchenko², K. Fibakh ${ }^{2}$, O. Lysenko ${ }^{1,3}$, O. Shynkaruk ${ }^{1}$}

${ }^{1}$ National University of Physical Education and Sport of Ukraine, Kyiv, Ukraine

${ }^{2}$ Taras Shevchenko National University of Kyiv, Kyiv, Ukraine

${ }^{3}$ Borys Hrinchenko University of Kyiv, Kyiv, Ukraine

Abstract. Indices of simple visual-motor reaction and reaction of choice of one of three signals for the right and left hand, those of reaction of choice of two of three signals have been investigated. In addition, dynamic muscular endurance was examined according to the tapping test indices for the right and left hand. Objective. Determination and comparison of the state of neurodynamic functions and dynamic muscular endurance of the hand movement of athletes specialized in cyclic sports event (kayaking and canoeing) and untrained persons (students). Methods. Analysis of scientific literature, testing, methods of mathematical statistics. Results. According to psychophysiological indices, athletes showed higher results, some differences reached the level of significance. As compared to untrained individuals, athletes demonstrated higher muscular endurance during the movements of the dominant hand and higher speed of information processing in the central nervous system, which was manifested in faster reactions of choosing two of the three signals and shorter time of central information processing. Latent periods of simple visual-motor reaction in the 
surveyed athletes and untrained individuals did not differ. The findings indicate changes primarily in the central links of the organization of motor programs as a result training, whereas the peripheral components of sensorimotor responses are less subjected to adjustment due to regular physical loads. The identified differences in the state of neurodynamic functions and the level of dynamic muscular endurance of the hand motion can have prognostic value and may be used to optimize sports improvement in this sports event.

Keywords: highly skilled athletes, state of neurodynamic functions, dynamic muscular endurance, rowing.

Постановка проблеми. У сучасному спорті вищих досягнень перемогу у змаганнях отримують за рахунок врахування багатьох оракторів, що впливають на успішний виступ спортсмена. Поряд із ретельно продуманою програмою тренувань, режимом навантажень все більшого значення набуває урахування індивідуальних типологічних особливостей спортсменів, що може мати вирішальне значення під час відбору їх у команду. Розуміння прогностичних критеріїв та оцінювання показників, що характеризують стан нейродинамічних функцій, $\epsilon$ актуальним завданням тренерів у ході фоормування команди та розробки стратегії тренувань.

Незважаючи на досить високу зацікавленість як дослідників, так і тренерів, кількісні та якісні критерії прогнозування стану нейродинамічних функцій все ще залишаються недостатньо розробленими. Слід зазначити, що на сьогодні відсутній єдиний підхід до методики дослідження та оцінювання результатів: зарубіжні учені займаються проблемами дослідження і оцінювання нейродинамічних характеристик спортсменів 3 використанням переважно психологічних методик, що, безумовно, призводить до недооцінювання біологічної компоненти [8, 22, 28, 32, 35]. Традиційно в Україні такі дослідження проводять лікарі та фрізіологи, що сприяє посиленню уваги до фрізіологічних механізмів і, певною мірою, призводить до недооцінювання психологічних механізмів поведінкових реакцій $[4,6,15,17]$.

У різних ссрерах життєдіяльності людини успішність праці, навчання, творчості, фрізичне i психічне здоров'я пов'язані з ії фрункціональним станом $[4,5,15]$. Він залежить від багатьох фракторів: мотивації, змісту праці, рівня сенсорного навантаження, вихідного рівня активності нервової системи, індивідуальних властивостей вищої нервової діяльності $[5,15]$. Так, люди із сильною нервовою системою менш стійкі до роботи в умовах монотонії, і в них раніше, ніж в осіб з слабкою нервовою системою, знижується рівень активності нервових процесів $[5,18]$. Дуже близьким до поняття функціонального стану $€$ поняття «психофрізіологічний стан», який, за визначенням $Є$. П. Ільїна, $€$ цілісною реакцією осо- бистості на зовнішні та внутрішні стимули, спрямованою на досягнення корисного результату $[1,3]$. На відміну від розуміння стану людини як простого комплексу чи сукупності показників, поняття психофрізіологічного стану розглядають як єдину систему, що саморегулюється [5]. Системна сутність психофрізіологічного стану людини полягає у тому, що він насамперед формується в процесі і під впливом конкретної діяльності і в той самий час зумовлює її ефективність $[5,7]$.

Для дослідження стану психосрізіологічних функцій під керівництвом М. В. Макаренка розроблено комп'ютерну систему «Діагност-1», яка дозволяє отримувати, автоматично реєструвати та статистично обробляти такі показники, як латентний період простої зорово-моторної реакції (ЛП ПЗМР), латентний період реакції вибору одного 3 трьох сигналів (ЛП РВ1-3), латентний період реакції вибору двох із трьох сигналів (ЛП РВ2-3), показники реакції на рухомий об'єкт, а також показники швидкості, якості та кількості переробки інфрормації у двох режимах «нав'язаного ритму» та «зворотного зв'язку», що визначають функціональну рухливість нервових процесів (ФРНП) та силу нервових процесів (СНП) [11-13, 21]. Саме показники швидкості, якості та кількості переробки інформації у двох режимах - «нав'язаного ритму» та «зворотного зв'язку» дають можливість оцінити здатність вищих відділів центральної нервової системи забезпечувати максимально можливий для кожного індивіда рівень швидкої дії за безпомилковим диференціюванням позитивних і гальмівних подразників з урахуванням швидкості, якості та кількості їх переробки. Ці показники зумовлені високогенетично детермінованими властивостями основних нервових процесів, а також властивостями функцій пам'яті, мислення, сприйняття та уваги [5, 12].

Мета дослідження - визначення і порівняння стану нейродинамічних функцій і динамічної м'язової витривалості руху кисті спортсменів і нетренованих осіб.

Роботу виконано у НДІ НУФВСУ відповідно до держбюджетної науково-дослідної теми «Технологія оцінки ризику травматизму спортсменів 
за електронейроміографрічними і психофрізіологічними показниками» (номер держреєстрації 0119U000307).

Методи дослідження: аналіз наукової літератури, тестування, методи математичної статистики.

Результати дослідження та їх обговорення. У дослідженні брали участь 20 кваліфікованих спортсменів (майстри спорту, майстри спорту міжнародного класу і заслужені майстри спорту) обох статей 19-32 років, вид спорту - веслування на байдарках і каное, спортивний стаж 6-20 років. До контрольної групи ввійшли 16 студентів обох статей 19-32 роки Київського національного університету імені Тараса Шевченка. У всіх обстежуваних домінантною виявилася права рука.

Для визначення стану нейродинамічних функцій, максимального темпу руху кисті (за методикою тепінг-тесту) використовували діагностичний комплекс «Діагност-1» [14]. Відповідно до мети роботи досліджували показники простої зоровомоторної реакції (ПЗМР) та реакції вибору одного з трьох сигналів (РВ1-3) для правої та лівої руки, показники реакції вибору двох із трьох сигналів (РВ2-3). Як розумове навантаження для переробки інформації застосовували предметні символи, а саме геометричні фрігури. В «оптимальному режимі» при пред'явленні та переробці зазначених стимулів проводили вивчення параметрів сенсомоторних реакцій різного ступеня складності, латентних періодів - ЛП ПЗМР, ЛП РВ1-3 та ЛП РВ2-3 і складових латентних періодів - моторних компонентів реакцій та часу центральної обробки інфрормації в реакціях вибору $[5,14]$.

Також досліджували динамічну м'язову витривалість (за показниками тепінг-тесту окремо для правої та лівої кисті) як у спортсменів, так і в контрольній групі - у нетренованих осіб. Динамічну м'язову витривалість, здатність усіх ланок рухового аналізатора до швидкості та витривалості характеризує, як зазначав М. В. Макаренко, максимальний темп руху кисті за методикою тепінг-тесту [14]. Суть цієї методики полягає у реєстрації кількості натискань правою чи лівою рукою певної клавіші клавіатури комп'ютера (допустимо використовувати спеціальні прилади, телеграфннй ключ або олівець 3 аркушем паперу) протягом 60 с, при цьому обстежуваний повинен працювати на максимумі вольових зусиль, навіть якщо темп руху у нього зменшується.

Статистичну обробку даних проводили за допомогою методів непараметричної статистики. Для опису вибіркового розподілу вказували медіани та міжквартильний розкид (Ме [25 \%; 75 \%]). Для порівняння незалежних вибірок використовували критерій Манна-Уітні. Критичний рівень значущості міжгрупових відмінностей під час перевірки статистичної гіпотези приймали рівним $p=0,05$ для парних порівнянь.

Під час проведення комплексних біологічних досліджень за участю спортсменів відповідно до принципів біоетики дотримувалися розробленої в лабораторії теорії і методики спортивної підготовки і резервних можливостей спортсменів НДІ НУФВСУ «Програми комплексного біологічного дослідження особливостей функціональних можливостей спортсменів», а також законодавства України про охорону здоров'я та Гельсінської декларації 2000 р., директиви Європейського товариства 86/609 щодо участі людей у медикобіологічних дослідженнях [21].

До групи обстежених увійшли спортсмени, які займаються циклічним видом спорту - веслуванням на байдарках і каное на довгі дистанції (10 000 м), що характеризується повторенням одних і тих самих рухових актів і високою функціональною стійкістю центральної нервової системи (ЦНС) до монотонії. Спеціальна витривалість у циклічних видах спорту, як відомо, залежить від довжини дистанції [16, 18]. Веслування на дистанції 500-1000 м характеризується навантаженнями анаеробно-аеробного характеру i стійкістю ЦНС до недостатнього кисневого постачання [18]. Крім того, робота на витривалість формує високу стійкість ЦНС до перешкод. Особлива здатність до довготривалих циклічних навантажень притаманна спортсменам із сильною врівноваженою нервовою системою і невисоким рівнем рухливості (флегматикам) [18].

За віком групи обстежених не відрізнялися (табл. 1). Виявлено тенденцію до більш високого рівня динамічної м'язової витривалості руху кисті субдомінантної руки у спортсменів порівняно з нетренованими особами, але ці відмінності за тестом Манна-Уітні не досягли рівня значущості. Проте для домінантної руки динамічна м'язова витривалість руху кисті була значуще більша $(p<0,05)$ у спортсменів порівняно з обстеженими студентами (див. табл. 1). За даними спеціальної літератури, максимальний темп руху кисті вищий в осіб зі слабкою нервовою системою, дещо поступаються їм за частотою постукувань представники з сильною нервовою системою, найнижчі показники за тепінг-тестом зазвичай мають особи з середньою силою нервової системи. Функціональна рухливість нервових процесів не чинить помітного впливу на максимальну частоту рухів [2]. 
ТАБЛИЦЯ 1 - Показники динамічної м'язової витривалості (тепінг-тест) спортсменів і нетренованих ocí $(n=36)$, Me [25\%, $75 \%$ ]

\begin{tabular}{|l|c|c|}
\hline \multirow{2}{*}{\multicolumn{1}{|c|}{ Показник }} & \multicolumn{2}{|c|}{ Група } \\
\cline { 2 - 3 } & $\begin{array}{c}\text { перша } \\
\text { (спортсмени), } \mathbf{n = 2 0}\end{array}$ & $\begin{array}{c}\text { друга (студенти), } \\
\mathbf{n}=\mathbf{1 6}\end{array}$ \\
\hline $\begin{array}{l}\text { Динамічної м'язової } \\
\text { витривалості руху кисті } \\
\text { домінантної (правої) } \\
\text { руки, натискань }\end{array}$ & $\begin{array}{c}\mathbf{4 0 6 , 0 0} \\
{[\mathbf{3 8 3 , 5 0 ; 4 2 7 , 5 0}]^{*}}\end{array}$ & $\begin{array}{c}\mathbf{3 7 4 , 5 0} \\
{[\mathbf{3 5 3 , 5 0 ;} \mathbf{3 9 1 , 5 0 ]}}\end{array}$ \\
\hline $\begin{array}{l}\text { Показник динамічної } \\
\text { м'язової витривалості } \\
\text { руху кисті субдомінантної } \\
\text { (лівої) руки, натискань }\end{array}$ & $\begin{array}{c}345,50 \\
{[329,50 ; 378,00]}\end{array}$ & $\begin{array}{c}321,50 \\
{[306,00 ; 355,50]}\end{array}$ \\
\hline
\end{tabular}

Примітка: * - p < 0,01 - значущі різниці між групами за тестом Манна-Уітні

Загалом, за психофізіологічними показниками спортсмени порівняно з контрольною групою продемонстрували вищі результати (табл. 2), деякі відмінності набули рівня значущості (р < $<0,05$, p $<0,01)$, що цілком узгоджується з відомими літературними даними про вплив фрізичних навантажень і занять різними видами спорту на формування і стан психофрізіологічних фрункцій [11-13]. За результатами проведених досліджень виділені групи значуще відрізнялися за такими показниками: латентний період реакції вибору одного з трьох сигналів (права рука), латентний період складної реакції вибору двох із трьох сигналів та час центральної обробки інформації в реакції вибору двох із трьох сигналів (див. табл. 2).
Слід окремо зазначити, що в представленому дослідженні як розумове навантаження для переробки іноормації застосовували предметні символи, а саме геометричні фрігури. Переробка образної інформації для фрігур здійснюється переважно за участю першої сигнальної системи [15] і вимагає значно більшого залучення фрізичних, когнітивних та енергетичних ресурсів [15, $29,34]$ порівняно з вербальними (словесними) подразниками. До складу першої сигнальної системи входить більше підкіркових та кіркових систем, які певною мірою дублюють одна одну, тим самим підвищуючи надійність системи $[27,31]$ й участь вищих фрункціональних резервів розумової працездатності [30]. Натомість, більш молоді вербальні фуннції, які належать до другої сигнальної системи та більше зв'язані з корою великих півкуль (особливо з лобними ділянками) [15], менш стабільні й мають менший нейрофрізіологічний ресурс [26].

За результатами проведених досліджень виділені групи за тестом Манна-Уітні значуще не відрізнялися за такими показниками: латентний період простої зорово-моторної реакції і моторний компонент простої зорово-моторної реакції (права та ліва рука), латентний період реакції вибору одного з трьох сигналів (ліва рука), моторний компонент і час центральної обробки інформації в реакції вибору одного з трьох сигналів (права та ліва рука), моторний компонент реакції вибору двох із трьох сигналів (див. табл. 2).

ТАБЛИЦЯ 2 - Психофізіологічні показники спортсменів і нетренованих осіб (n = 36), Мe [25 \%, 75 \%]

\begin{tabular}{|c|c|c|}
\hline \multirow{2}{*}{ Показник, мс } & \multicolumn{2}{|c|}{ Група } \\
\hline & $\begin{array}{l}\text { перша (спортсмени), } \\
\mathrm{n}=20\end{array}$ & $\begin{array}{c}\text { друга (студенти), } \\
n=16\end{array}$ \\
\hline \multicolumn{3}{|c|}{ Проста зорово-моторна реакція } \\
\hline $\begin{array}{l}\text { Латентний період простої зорово-моторної реакції (права } \\
\text { рука) }\end{array}$ & $\begin{array}{c}252,25 \\
{[242,48 ; 274,52]}\end{array}$ & $\begin{array}{c}267,75 \\
{[250,46 ; 301,64]}\end{array}$ \\
\hline $\begin{array}{l}\text { Моторний компонент простої зорово-моторної реакції } \\
\text { (права рука) }\end{array}$ & $\begin{array}{c}105,89 \\
{[80,39 ; 137,07]}\end{array}$ & $\begin{array}{c}113,20 \\
{[100,05 ; 135,84]}\end{array}$ \\
\hline \multicolumn{3}{|c|}{ Реакція вибору одного з трьох сигналів } \\
\hline $\begin{array}{l}\text { Латентний період реакції вибору одного з трьох сигналів } \\
\text { (права рука) }\end{array}$ & $\begin{array}{c}371,95[353,11 \\
390,33]^{*}\end{array}$ & $\begin{array}{l}396,78[380,50 \\
410,56]\end{array}$ \\
\hline $\begin{array}{l}\text { Моторний компонент реакції вибору одного з трьох } \\
\text { сигналів (права рука) }\end{array}$ & $\begin{array}{c}117,33 \\
{[88,22 ; 139,72]}\end{array}$ & $\begin{array}{c}130,83 \\
{[110,85 ; 146,82]}\end{array}$ \\
\hline $\begin{array}{l}\text { Час центральної обробки інформації в реакції вибору } \\
\text { одного з трьох сигналів (права рука) }\end{array}$ & $\begin{array}{c}104,82 \\
{[91,07 ; 131,78]}\end{array}$ & $\begin{array}{c}115,16 \\
{[101,46 ; 139,27]}\end{array}$ \\
\hline \multicolumn{3}{|c|}{ Реакція вибору двох із трьох сигналів } \\
\hline Латентний період реакції вибору двох із трьох сигналів & $\begin{array}{c}434,20 \\
{[395,75 ; 459,00]^{*}}\end{array}$ & $\begin{array}{c}464,64 \\
{[440,97 ; 492,63]}\end{array}$ \\
\hline Моторний компонент реакції вибору двох із трьох сигналів & $\begin{array}{c}118,62 \\
{[97,39 ; 135,17]}\end{array}$ & $\begin{array}{c}129,96 \\
{[106,13 ; 148,92]}\end{array}$ \\
\hline $\begin{array}{l}\text { Час центральної обробки інформації в реакції вибору } \\
\text { двох із трьох сигналів }\end{array}$ & $\begin{array}{c}166,44 \\
{[152,38 ; 180,38]^{* *}}\end{array}$ & $\begin{array}{c}196,18 \\
{[174,41 ; 207,78]}\end{array}$ \\
\hline
\end{tabular}

Примітки: * $-p<0,05,{ }^{* *}-p<0,01$ - значущі різниці між групами за тестом Манна-Уітні. 
Для досягнення високих результатів у циклічних видах спорту велику роль відіграє сила нервових процесів [11, 18]. Слід зазначити, що латентні періоди складної реакції вибору можуть розглядатися як додаткові показники сили і функціональної рухливості нервових процесів $[14,15]$. Хоча деякі відмінності між групами спортсменів і нетренованих осіб не набули рівня значущості, в даному випадку можна відзначити, що латентні періоди складної реакції вибору (двох із трьох сигналів) у спортсменів були менші, ніж у нетренованих осіб ( $p<0,05)$, що може свідчити про більший розвиток сенсомоторної витривалості, сили нервових процесів у спортсменів порівняно з нетренованими особами (див. табл. 2).

Отримані дані підтверджують результати багатьох вітчизняних і зарубіжних дослідників про вплив на фрормування та стан нейродинамічних функцій у різні вікові періоди фрізичних навантажень, зокрема занять спортом [9, 10, 20, 23, 24]. Відомо, що регулярні заняття одним з видів спорту впливають на показники психофрізіологічних фрункцій, властивості основних нервових процесів, психологічні характеристики спортсменів і студентів, що займаються руховою активністю $[11,18,19,25,33]$.

Виявлені відмінності стану нейродинамічних функцій і рівня динамічної м'язової витривалості руху кисті можуть мати прогностичну цінність і

\section{Література}

1. Ильин ЕП. Дифференциальная психофизиология [Differential psychophysiology]. Санкт-Петербург; 2001. 464 с.

2. Ильин ЕП. Психомоторная организация человека [Human psychomotor organization]. Санкт-Петербург: Питер; 2003. 384 с.

3. ИльинЕП. Психофизиология состояний человека [Psychophysiology of human states]. Санкт-Петербург: Питер; 2005. 412 c.

4. Кокун ОМ. Оптимізація адаптаційних можливостей людини: психофрізіологічний аспект забезпечення діяльності: Монографія [Optimization of human adaptive capacity: psychophysiological aspect of activity support: Monograph]. Київ: Міленіум; 2004. 265 c.

5. Кокун ОМ. Психофізіологія. Навч. посібник [Psychophysiology. Tutorial]. Київ: Центр навчальної літератури; 2006. 184 с.

6. Коробейников Г, Приступа $€$, Коробейнікова Л, Бріскин Ю. Оцінювання психофізіологічних станів у спортсменів [Evaluation of psychophysiological states in athletes]. Львів: ЛДУФК;2013.312 c.

7. Куценко ТВ. Стан психофізіологічних функцій у дітей молодшого шкільного віку [The state of primary schoolchildren psychophysiological functions]: Автореф. дис.канд-та біол. наук: 03.00.13. Київ; 2000. 18 c

8. Лизогуб В, Пустовалов В, Супрунович В, Гречуха С. Сучасні підходи до реалізації відбору футболістів високої кваліфікації за показниками нейродинамічних властивостей вищих відділів центральної нервової системи [Modern approaches to the implementation of the selection of highly skilled footbalers according to the indices of neurodynamic properties of the higher parts of the central nervous system]. Слобожанський науково-спортивний вісник. 2017; 2: 47-52. doi:10.15391/snsv.2017-2.008

9. Лизогуб ВС, Пустовалов ВО, Супрунович ВО, Коваль ЮВ. Підготовленість футболістів 13-14 років з різними індивідуально-типологічними властивостями вищих відділів центральної нервової системи [Fitness використовуватися для оптимізації спортивного удосконалення в даному виді спорту.

\section{Висновки}

1. Спортсмени порівняно 3 нетренованими особами продемонстрували вищу м'язову витривалість під час рухів кисті домінантної руки та вищу швидкість обробки інорормації в ЦНС, що виявлялося у швидших реакціях вибору двох із трьох сигналів та коротшим часом центральної обробки інформації. Латентні періоди простої зорово-моторної реакції в обстежених спортсменів і нетренованих осіб не відрізнялися.

2. Отримані дані свідчать про зміни передусім у центральних ланках організації рухових програм унаслідок тренування, тоді як периферичні компоненти сенсомоторних реакцій меншою мірою зазнають перебудови внаслідок регулярних фрізичних навантажень.

3. Виявлені відмінності стану нейродинамічних фрункцій і рівня динамічної м'язової витривалості руху кисті можуть мати прогностичну цінність і використовуватися для оптимізації спортивного вдосконалення в даному виді спорту.

Перспективи подальших досліджень передбачають подальше вивчення психофрізіологічних показників у спортсменів, які спеціалізуються в різних видах спорту та в процесі професійної діяльності зазнають впливу навантажень різних типів.

levels of footballers aged 13-14 with different individual-typological properties of the higher departments of the central nervous system]. Наука і освіта. 2014 8: 114-118.

10. Лысенко ЕН, Шинкарук ОА. Влияние на проявление нейродинамических свойств спортсменов полового диморфизма и напряженной физической работы [Sexual dimorphism and strenuous physical work influence on the manifestation of neurodynamic properties of athletes]. Наука и спорт: современные тенденции. 2015; 6(1): 11-18

11. Макаренко MB, Лизогуб ВС. Онтогенез психофізіологічних функцій людини [Ontogenesis of human psychophysiological functions]. Черкаси; 2011. 256 c

12. Макаренко MB, Лизогуб BC, Безкопильний ОП. Нейродинамічні властивості спортсменів різної кваліфікації та спеціалізації [Neurodynamic properties of athletes of different qualifications and specialization]. Актуальні проблеми фізичної культури і спорту. 2004; 4: 105-109.

13. Макаренко $\mathrm{H}$, Лизогуб В, Безкопыльный А. Формирование свойств нейродинамических функций у спортсменов [Formation of the properties of neurodynamic functions in athletes]. Наука в олимпийском спорте. 2005; 2: 80-85.

14. Макаренко МВ, Лизогуб ВС, Безкопильний ОП. Методичні вказівки до практикуму з диференціальної психофрізіології та фрізіології вищої нервової діяльності людини [Methodical instructions to the practical works on differential psychophysiology and physiology of higher human nervous activity]. Київ-Черкаси; 2014. 102 с

15. Макарчук МЮ, Куценко ТВ, Кравченко ВІ, Данилов СА. Психофрізіологія: навчальний посібник [Psychophysiology: textbook]. Київ; 2011: 329 с

16. Платонов ВН. Система подготовки спортсменов в олимпийском спорте. Общая теория и ее практические приложения: учебник [для тре- 
неров] [The system of training athletes in the Olympic sport. General theory and its practical applications: a textbook [for trainers]: в 2 кн. Кн. 1. Київ; 2015. $680 \mathrm{c}$.

17. Ровний АС, Ільїн ВМ, Лизогуб ВС, Ровна ОО. Фізіологія спортивної діяльності [Physiology of sports activity]. Харків: ХНАДУ; 2015. 556 c.

18. Солодков АС, Сологуб ЕБ. Физиология человека. Общая. Спортивная. Возрастная: Учебник [Human physiology. The general. Sports. Age: Textbook. Москва; 2001. 620 c.

19. Тукаев СВ, Долгова ЕН, Вашека ТВ, Федорчук СВ, Лысенко ЕН, Колосова ЕВ, Гаврилець ЮД, Зима ИГ, Ризун ВВ, Шинкарук ОА. Индивидуально-психологические характеристики учащейся молодежи, занимающейся разными видами спорта [Individual and psychological characteristics of students engaged in different sports events]. Спортивна медицина і фізична реабілітація. 2017; 1: 64-71.

20. Шинкарук О, Лысенко Е. Влияние полового диморфизма и физических нагрузок на проявление нейродинамических свойств у спортсменов высокого класса [Influence of sexual dimorphism and physical loads on the manifestation of neurodynamic properties in high-class athletes]. Наука в Олимпийском спорте. 2004; 1: 75-79.

21. Шинкарук ОА, Лисенко ОМ, Гуніна ЛМ, Карленко ВП, Земцова II, Олішевський СВ. Медико-біологічне забезпечення підготовки спортсменів збірних команд України з олімпійських видів спорту [Medicobiological support of training of athletes of national teams of Ukraine in the Olympic sports events]. за заг. ред. О. А. Шинкарук. Київ; 2009. 144 с.

22. Bastias $G$, Villarroel $L$, Zuniga $D$ et all. Academic performance of medical students: a predictable result? Rev. Med. Chil. 2000; 128(6): 671-678.

23. Fedorchuk S, Petrushevskyi Y. The state of psychophysiological functions in handball players with different experience of sports training. Bulletin of Taras Shevchenko National University of Kyiv-Biology. 2020; 81(2): 42-45. DOl: http://dx.doi.org/10.17721/1728_2748.2020.81.42-45

24. Fedorchuk S, Lysenko O, Romanyuk V. Neurodynamic properties and psychological characteristics of high qualification sportships with different sports trainings. Bulletin of Taras Shevchenko National University of Kyiv -

lanasvet778899@gmail.com

viktoriia.kravchenko@knu.ua

c.fiebach@icloud.com

markizalus14@gmail.com

shi-oksana@ukr.net
Problems of Physiological Functions Regulation. 2018. 24(1): 27-31. DOI: http://dx.doi.org/10.17721/2616_6410.2018.24.27-31

25. Fedorchuk S, Lysenko O, Shynkaruk 0 . Constructive and nonconstructive coping strategies and psychophysiological properties of elite athletes. European Psychiatry, Elsevier. 2019; 56: 306.

26. Hartman P, Cockbum J. Dividing attention between cognitive and motor tasks in neurological rehabilitation. Neuropsychol. Rehabil. 1998; 8: 155

27. Horak FB. Postural orientation and equilibrium: what do we need to know about neural control of balance to prevent falls? Age and Ageing. 2006; 35(2): 7.

28. Yeung RR. The effect of exercise on mood state. Journal of Psychosomatitic Research. 1996; 40(2): 123-141.

29. Kotsan IYa, Kozachuk NA, Kuznetsov IP. EEG correlation dimension indicies, related to general and creative tasks performance productivity level. European Applied Sciences. 2014: 8-10.

30. Lizohub V, Chernenko N, Kozhemyako T, Palabiyik A, Bezkopulna S. Research of Functional Reserves of Mental Performance. Lesya Ukrainka Eastern European National University Scientific Bulletin. Series: Biological Sciences. 2018; 8(381): 102-107. doi.org/10.29038/2617-4723-2018-381-102107

31. Maurer C, Mergner R, Peterka R. Multisensory control of human upright stance. Exp. Brain Res. 2006; 171: 231

32. O'Sullivan D, Zuckerman M, Kraft M. Personality characteristics of male and female participants in team sports. Personality and Individual Differences. 1998; 25: 119-128.

33. Shynkaruk O, Lysenko O, Fedorchuk S. Assessment of psychophysiological characteristics of the representatives of cyclic sports. European Psychiatry, Elsevier. 2019; 56: 679-680.

34. Sperry RW. Mind-brain interaction: mentalism, yes; dualism, no Neuroscience. 1980; 5: 195-206.

35. Tomczak M, Walczak M, Breczewski G. Selected psychological determinants of sports results in senior fencers. Human movement. 2012; 13(2): 161-169. 